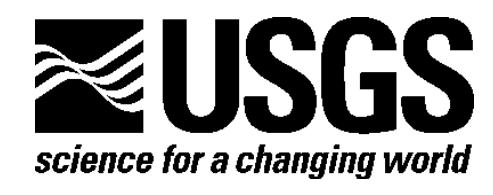

Prepared In Cooperation with the National Park Service

\title{
Water Chemistry and Electrical Conductivity Database for Rivers in Yellowstone National Park, Wyoming
}

By Laura E. Clor, R. Blaine McCleskey, Mark A. Huebner, Jacob B. Lowenstern, Henry P. Heasler, Dan L. Mahony, Tim Moloney, and William C. Evans

Data Series 632

U.S. Department of the Interior

U.S. Geological Survey 


\section{U.S. Department of the Interior \\ KEN SALAZAR, Secretary}

\section{U.S. Geological Survey \\ Marcia K. McNutt, Director}

U.S. Geological Survey, Reston, Virginia 2012

For product and ordering information:

World Wide Web: http://www.usgs.gov/pubprod

Telephone: 1-888-ASK-USGS

For more information on the USGS - the Federal source for science about the Earth,

its natural and living resources, natural hazards, and the environment:

World Wide Web: http://www.usgs.gov

Telephone: 1-888-ASK-USGS

Suggested citation:

Clor, L.E., McCleskey, R.B., Huebner, M.A., Lowenstern, J.B., Heasler, H.P., Mahony, D.L., Moloney, Tim, and Evans, W.C., 2012, Water chemistry and electrical conductivity database for rivers in Yellowstone National Park, Wyoming: U.S. Geological Survey Data Series 632, 18 p. and data tables, available at $h$ ttp://pubs.usgs.gov/ds/632/.

Any use of trade, product, or firm names is for descriptive purposes only and does not imply endorsement by the U.S. Government.

Although this report is in the public domain, permission must be secured from the individual copyright owners to reproduce any copyrighted material contained within this report. 


\section{Contents}

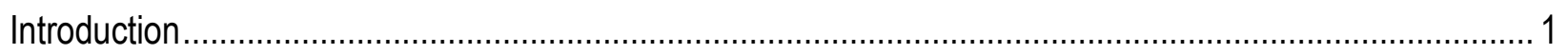

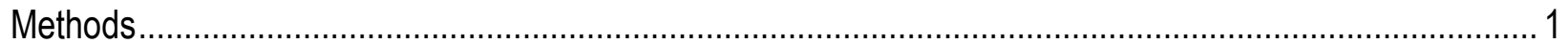

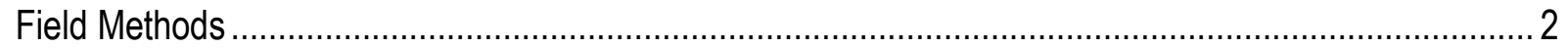

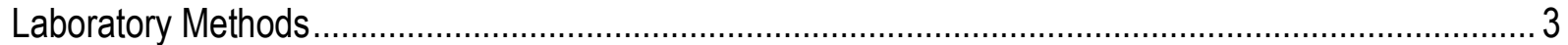

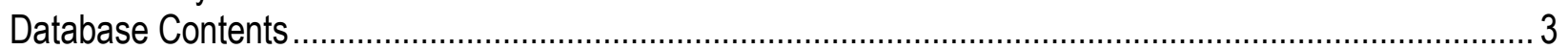

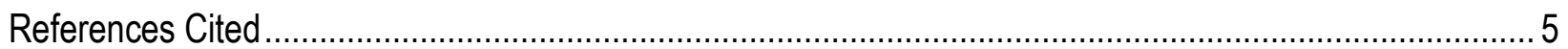

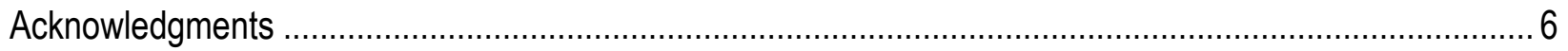

Appendix: Photo documentation of Instruments and Field Sites........................................................... 8

\section{Figure}

Figure 1. Map of sampling sites in Yellowstone National Park ....................................................... 7

\section{Data}

Workbook file in several formats . .http://pubs.usgs.gov/ds/632/ds632_data/ 


\section{Conversion Factors}

\begin{tabular}{lll}
\hline \multicolumn{1}{c}{ Multiply } & \multicolumn{1}{c}{ By } & \multicolumn{1}{c}{ To obtain } \\
\hline inch (in.) & 2.54 & centimeter $(\mathrm{cm})$ \\
foot (ft) & 0.3048 & meter $(\mathrm{m})$ \\
mile (mi) & 1.609 & kilometer $(\mathrm{km})$ \\
cubic foot per second (cfs) & 0.02832 & cubic meter per second $\left(\mathrm{m}^{3} / \mathrm{s}\right)$ \\
\hline
\end{tabular}

Temperature in degrees Celsius $\left({ }^{\circ} \mathrm{C}\right)$ may be converted to degrees Fahrenheit $\left({ }^{\circ} \mathrm{F}\right)$ as follows: ${ }^{\circ} \mathrm{F}=\left(1.8 \times{ }^{\circ} \mathrm{C}\right)+32$

Horizontal coordinate information is referenced to the North American Datum of 1983 (NAD 83).

\section{Explanation of Abbreviations}

$\begin{array}{ll}\text { Temp } & \text { temperature } \\ \text { EC } & \text { electrical conductivity } \\ \text { DO } & \text { dissolved oxygen } \\ \text { CFS } & \text { cubic feet per second } \\ { }^{\circ} \mathrm{C} & \text { degrees Celsius } \\ \mu \mathrm{S} / \mathrm{cm} & \text { microsiemens per centimeter } \\ \mathrm{ft} & \text { foot } \\ \mathrm{m} & \text { meter } \\ \mathrm{cm} & \text { centimeter } \\ \mathrm{mm} & \text { millimeter } \\ \mu \mathrm{m} & \text { micrometer } \\ \mathrm{mL} & \text { milliliter } \\ \mathrm{mg} / \mathrm{L} & \text { miligrams per liter } \\ \mathrm{MDT} & \text { Mountain Daylight Time }\end{array}$




\section{Water Chemistry and Electrical Conductivity Database for Rivers in Yellowstone National Park, Wyoming}

By Laura E. Clor, R. Blaine McCleskey, Mark A. Huebner, Jacob B. Lowenstern, Henry P. Heasler, Dan L. Mahony, Tim Moloney, and William C. Evans

\section{Introduction}

Chloride flux has been used to estimate heat flow in volcanic environments since the method was developed in New Zealand by Ellis and Wilson (1955). The method can be applied effectively at Yellowstone, because nearly all of the water discharged from its thermal features enters one of four major rivers (the Madison, Yellowstone, Snake, and Falls Rivers) that drain the park, and thus integration of chloride fluxes from all these rivers provides a means to monitor the total heat flow from the entire Yellowstone volcanic system (Fournier and others, 1976; Fournier, 1979). Fournier (1989) summarized the results and longterm heat-flow trends from Yellowstone, and later efforts that applied the chloride inventory method to estimate heat flow were described by Ingebritsen and others (2001) and Friedman and Norton (2007). Most recently, the U.S. Geological Survey (USGS), in conjunction with the National Park Service, has provided publicly accessible reports on solute flux, based on periodic sampling at selected locations (Hurwitz and others, 2007a,b). While these studies have provided a wealth of valuable data, winter travel restrictions and the great distances between sites present significant logistical challenges and have limited collection to a maximum of 28 samples per site annually.

This study aims to quantify relations between solute concentrations (especially chloride) and electrical conductivity for several rivers in Yellowstone National Park (YNP), by using automated samplers and conductivity meters. Norton and Friedman (1985) found that chloride concentrations and electrical conductivity have a good correlation in the Falls, Snake, Madison, and Yellowstone Rivers. However, their results are based on limited sampling and hydrologic conditions and their relation with other solutes was not determined. Once the correlations are established, conductivity measurements can then be used as a proxy for chloride concentrations, thereby enabling continuous heat-flow estimation on a much finer timescale and at lower cost than is currently possible with direct sampling. This publication serves as a repository for all data collected during the course of the study from May 2010 through July 2011, but it does not include correlations between solutes and conductivity or recommendations for quantification of chloride through continuous electrical conductivity measurements. This will be the object of a future document.

\section{Methods}

Equipment was installed during May and June of 2010 at four monitoring sites near existing USGS stream gages within YNP (fig. 1):

- Firehole River near West Yellowstone, MT (at Firehole Canyon), USGS gaging site\# 06036905 
- Firehole River above Old Faithful, \# 06036805

- Yellowstone River at Yellowstone Lake Outlet (below Fishing Bridge), \# 06186500

- Tantalus Creek at Norris Junction (above Tantalus weir), \# 06036940

\section{Field Methods}

One Aqua TROLL 200 (made by In-Situ Inc.) was deployed at each monitoring site (appendix, photo 1). The Aqua TROLL instruments were set up to measure and record water temperature, pressure (as a proxy for water depth), and electrical conductivity, both at ambient temperature and adjusted to a reference temperature of $25^{\circ} \mathrm{C}$, at 15 -min intervals. The instruments were contained within 10- or 20-ft sections of 1.5-in-diameter PVC pipe, extending as far as practical into the main flow of the channel, oriented semi-perpendicular to the bank, and anchored to the streambed with rebar. Holes drilled into the lowermost $2 \mathrm{ft}$ of the PVC pipe allow water to flow freely past the instrument (appendix, photo 2). The pipe extended onto the stream bank such that the cabling can be accessed and data downloaded without moving the instrument (see appendix photos 3-5, 8-11).

Additional monitoring instruments were temporarily installed at Lone Star Geyser (fig. 1) to characterize the contribution of the discharge from Lone Star Geyser to the conductivity and chemistry of the Firehole River. This geyser is the only substantial source of thermal water upstream of the Old Faithful site. The instruments included a Hydrolab MS 5 multiparameter probe (Hach Company) installed in the Firehole River channel $200 \mathrm{~m}$ downstream of Lone Star Geyser that collected temperature, electrical conductivity, $\mathrm{pH}$, and dissolved oxygen data at 10min intervals from June 2 to June 6, 2010, and a Hobo Pro Series datalogger (Onset Computer Corporation) installed in the geyser's main outflow channel that recorded Lone Star Geyser eruptions by collecting temperature data at 1-min intervals, from June 2 through July 17, 2010. A second Hydrolab was deployed at the Old Faithful site over the same period for comparison purposes.

Stream discharge, stage, and water temperature were measured at the adjacent USGS gaging stations at 15-min intervals. These data, provided by the USGS National Water Information System (NWIS) and the USGS Montana Water Science Center, are used for comparison.

Water samples were collected from the monitoring sites within about $5 \mathrm{~m}$ of the Aqua TROLL instruments. Samples were collected either hourly or every $12 \mathrm{hr}$ using an automatic ISCO model 6712C sampler (Teledyne Isco, Inc.) and were stored in pre-cleaned $500 \mathrm{~mL}$ HDPE bottles until processed (appendix photos 6, 7, 10). The twice-daily samples were usually collected at 05:00 and 17:00 MDT to correspond with the times of flow minimum and maximum, respectively. Occasionally, additional sets of hourly and twice-daily samples were collected at Firehole Canyon and Tantalus Creek. At Tantalus Creek, the collection time of the second sample set was shifted to 11:00 and 23:00 MDT.

To address the possible issue of post-collection evaporation of the warm Tantalus Creek samples, an experiment was performed in which duplicate samples were collected every $6 \mathrm{hr}$ into two bottles, one of which contained 10-mm-diameter hollow plastic balls that float on the sample surface to reduce evaporation (sample ID includes " $b$ " in the accompanying workbook database).

Once collected, samples were removed from the auto-sampler to the USGS field lab in Mammoth Hot Springs for filtering and shipment to USGS laboratories for chemical analysis. At or near the time of filtering, the temperature, electrical conductivity, and $\mathrm{pH}$ of each sample was 
measured with a YSI 63 handheld $\mathrm{pH}$ and conductivity meter from YSI, Inc. (titled "Lab Measurements", accompanying workbook database).

Samples were processed using a peristaltic pump and were filtered using a $0.45 \mu \mathrm{m}$ capsule filter. Two 60-mL splits of the filtered water were retained for chemical analyses, including an unacidified (FU) sample for determination of anion concentrations and a nitric acidpreserved $\left(\mathrm{FA} ; 1 \% \mathrm{v} / \mathrm{v}\right.$ concentrated trace-metal grade $\left.\mathrm{HNO}_{3}\right)$ sample for cation and trace metal analyses.

\section{Laboratory Methods}

Concentrations of chloride, fluoride, bromide, and sulfate were determined with a Dionex ion chromatograph ICS-2000 at the USGS in Menlo Park, California. Analytical errors for these constituents are typically $<5 \%$. Total alkalinity as bicarbonate was determined with an Orion 940/960 autotitrator (Barringer and Johnsson, 1996), at the USGS in Boulder, Colorado. Fifteen milliliters of sample were titrated with $0.01 \mathrm{~N}$ sulfuric acid to the bicarbonate end-point. The analytical error in alkalinity concentrations is $<5 \%$. Concentrations of major cations and trace metals (Al, As, B, Ba, Be, Ca, Cd, Co, Cr, Cu, Fe, K, Li, Mg, Mn, Mo, Na, Ni, Pb, Sb, Se, SiO $\mathrm{Sr}, \mathrm{V}$, and $\mathrm{Zn}$ ) were determined using inductively coupled plasma-atomic emission spectrometry (ICP-AES; Leeman Labs model DRE) at the USGS in Boulder, Colorado, following the methods described by Ball and others (2010).

Several techniques are used to assure the quality of the analytical data. These techniques included calculation of charge imbalance, analysis of USGS standard reference water samples (SRWS), and replicate determinations in the laboratory. The charge imbalance calculated using WATEQ4F (Ball and Nordstrom, 1991) is less than $\pm 10 \%$ for all samples.

\section{Database Contents}

The database is a workbook file in several formats that contains electrical conductivity, temperature, and discharge data from both the Aqua TROLL instruments and USGS gages at 15min intervals, as well as chemical analyses of discrete samples for each site. Because the samples were collected on different time intervals than the conductivity, the data are presented in two separate spreadsheets for each site. One spreadsheet contains the conductivity, discharge, and other physical parameters and is titled with the name of the site followed by "cond", and a second spreadsheet contains the chemistry data and is titled with the site name followed by "chem". An additional spreadsheet titled "locations" contains the coordinates and elevations of each site, and a spreadsheet titled "Lone Star" contains all data collected at the site near Lone Star Geyser. The time stamp on the data in all the "cond" spreadsheets is in local time, indicating that Daylight Savings Time was observed, where applicable. All of the water samples listed in the "chem" spreadsheets were collected during the summer months, and their time stamps are, therefore, in Mountain Daylight Time (MDT).

Data from the Aqua TROLL instruments begins at the time of installation (May or June 2010) and ends with the most recent data retrieval in July 2011. The Fishing Bridge instrument was removed for the winter season in late September 2010 and was not replaced during the 2011 season. The Tantalus Creek instrument was fouled in a storm on October 23, 2010, and subsequent data has, therefore, been omitted from this report.

Column headings in the spreadsheet are explained below (*, data provided by USGS Montana Water Science Center). Data from USGS gaging stations are provisional and subject to 
revision until they have been thoroughly reviewed and received final approval. Provisionality columns have no heading ( $\mathrm{p}$, provisional; blank, approved).

Locations spreadsheet
A. Name
B. Site ID, USGS gaging station identification number
C. Latitude, decimal degrees, NAD 83 coordinate system
D. Longitude, decimal degrees, NAD 83 coordinate system
E. Elevation $(\mathrm{ft})$

Conductivity spreadsheets
A. Date and Time, local time
B. Temp, of water $\left({ }^{\circ} \mathrm{C}\right)$, from Aqua TROLL
C. Depth, of Aqua TROLL probe $(\mathrm{cm})$
D. Electrical Conductivity $(\mu \mathrm{S} / \mathrm{cm})$, from Aqua TROLL
E. Electrical Conductivity at $25^{\circ} \mathrm{C}(\mu \mathrm{S} / \mathrm{cm})$, from Aqua TROLL
F. Discharge*(cfs)
G. Provisionality of discharge data
H. Stage*(ft)
I. Provisionality of stage data
J. Water Temp* $\left({ }^{\circ} \mathrm{C}\right)$
K. Provisionality of water temperature data

Chemistry spreadsheets
A. Sample ID
B. Date and Time of Collection, in MDT
C. EC@25, electrical conductivity at $25^{\circ} \mathrm{C}(\mu \mathrm{S} / \mathrm{cm})$, measured with YSI 63 meter at the time of filtration
D. $\mathrm{pH}$, measured with YSI 63 meter at the time of filtration
E. Temp $\left({ }^{\circ} \mathrm{C}\right)$, measured with YSI 63 meter at the time of filtration
F. Filter Date, day on which sample was filtered and processed for shipping to analyzing laboratory
G. Lab Meas. Date, day on which temp, EC@25, and pH measurements above were made
$\mathrm{H}$. through $\mathrm{AK}$. Chemical analyses of the following ions: $\mathrm{Ca}, \mathrm{Mg}, \mathrm{Na}, \mathrm{K}$, Alkalinity*, $\mathrm{SO}_{4}, \mathrm{Cl}, \mathrm{F}, \mathrm{Al}, \mathrm{As}, \mathrm{B}, \mathrm{Ba}, \mathrm{Be}, \mathrm{Br}, \mathrm{Cd}, \mathrm{Co}, \mathrm{Cr}, \mathrm{Cu}, \mathrm{Fe}, \mathrm{Li}, \mathrm{Mn}, \mathrm{Mo}, \mathrm{Ni}, \mathrm{Pb}, \mathrm{Sb}^{*}, \mathrm{Se}^{*}$, $\mathrm{SiO}_{2}, \mathrm{Sr}, \mathrm{V}, \mathrm{Zn}(\mathrm{mg} / \mathrm{L})$. Alkalinity represented as $\mathrm{mg} / \mathrm{L} \mathrm{HCO}_{3}$. Note: parameters marked with * were not analyzed at every site.
Lone Star spreadsheet

A. Date and Time, in MDT, same time stamps for both Lone Star and Old Faithful data

B. Lone Star Temp $\left({ }^{\circ} \mathrm{C}\right)$ 
C. Lone Star $\mathrm{pH}$

D. Lone StarEC@25, electrical conductivity at $25^{\circ} \mathrm{C}(\mu \mathrm{S} / \mathrm{cm})$

E. Lone Star DO, dissolved oxygen $(\mathrm{mg} / \mathrm{L})$

F. Old Faithful Temp $\left({ }^{\circ} \mathrm{C}\right)$

G. Old Faithful $\mathrm{pH}$

H. Old Faithful EC@25, electrical conductivity at $25^{\circ} \mathrm{C}(\mu \mathrm{S} / \mathrm{cm})$

I. Old Faithful DO, dissolved oxygen $(\mathrm{mg} / \mathrm{L})$

J. (blank)

K. (blank)

L. Date and Time, in MDT, of Lone Star outflow channel temp measurements (1-min interval)

M. Temp $\left({ }^{\circ} \mathrm{C}\right)$ in Lone Star outflow channel

\section{References Cited}

Ball, J.W., McCleskey, R.B., and Nordstrom, D.K., 2010, Water-chemistry data for selected springs, geysers, and streams in Yellowstone National Park, Wyoming, 2006-2008: U.S. Geological Survey Open-File Report 2010-1192, 109 p.

Ball, J.W., and Nordstrom, D.K., 1991, User's manual for WATEQ4F, with revised thermodynamic data base and test cases for calculating speciation of major, trace, and redox elements in natural waters: U.S. Geological Survey Open-File Report 91-183, $189 \mathrm{p}$.

Barringer, J.L., and Johnsson, P.A., 1996, Theoretical considerations and a simple method for measuring alkalinity and acidity in low-pH waters by Gran titration: U.S. Geological Survey Water-Resources Investigations Report 89-4029, 36 p.

Ellis, A.J., and Wilson, S.H., 1955, The heat from the Weirakei-Taupo thermal region calculated from the chloride output, N.Z.: Journal of Science and Technology, sec. B 36, p. 622-631.

Fournier, R.O., 1979, Geochemical and hydrologic considerations and the use of enthalpychloride diagrams in the prediction of underground conditions in hot-spring systems: Journal of Volcanology and Geothermal Research, v. 5, p. 1-16.

Fournier, R.O., 1989, Geochemistry and dynamics of the Yellowstone National Park hydrothermal system: Annual Review of Earth and Planetary Sciences, v. 17, p. 13-53.

Fournier, R.O., White, D.E., and Truesdell, A.H., 1976, Convective heat flow in Yellowstone National Park, in Proceedings of the 2nd U.N. Symposium on the Development and Use of Geothermal Resources, San Francisco: Washington, D.C., U.S. Government Printing Office, v. 1, p. 731-739.

Friedman, I., and Norton, D.R., 2007, Is Yellowstone losing its steam? - Chloride flux out of Yellowstone National Park, in Morgan, L.A., ed., Integrated geoscience studies in the greater Yellowstone area-Volcanic, tectonic, and hydrothermal processes in the Yellowstone geoecosystem: U.S. Geological Survey Professional Paper 1717, p. 271-298. 
Hurwitz, S., Eagan, S., Heasler, H., Lowenstern, J.B., 2007a, River chemistry and solute flux in Yellowstone National Park: U.S. Geological Survey Digital Data Series 278, version 3, available at $h t t p: / / p u b s . u s g s . g o v / d s / 2007 / 278 /$.

Hurwitz, S., Lowenstern J.B., Heasler, H., 2007b, Spatial and temporal geochemical trends in the hydrothermal system of Yellowstone National Park-Inferences from river solute flux: Journal of Volcanology and Geothermal Research, v. 162, p. 149-171, doi:10.1016/j.jvolgeores.2007.01.003.

Ingebritsen, S.E., Galloway, D.L., Colvard, E.M., Sorey, M.L., Mariner, R.H., 2001, Timevariation of hydrothermal discharge at selected sites in the western United StatesImplications for monitoring: Journal of Volcanology and Geothermal Research, v. 111, p. $1-23$.

Norton D. R., and Friedman I., 1985, Chloride flux out of Yellowstone National Park: Journal of Volcanology and Geothermal Research, v. 26, p. 231-250.

\section{Acknowledgments}

Funds were made available through the American Recovery and Reinvestment Act and distributed to the Volcano Hazards Program. We appreciate the assistance of Christie Hendrix and Stacey Gunther of Yellowstone National Park in reviewing our research permits. This study endeavors to further the pioneering work of Irving Friedman, Robert Fournier, Steve Ingebritsen, and Shaul Hurwitz, and could not have been possible without their efforts. We thank Kirk Nordstrom for his suggestions and support. 


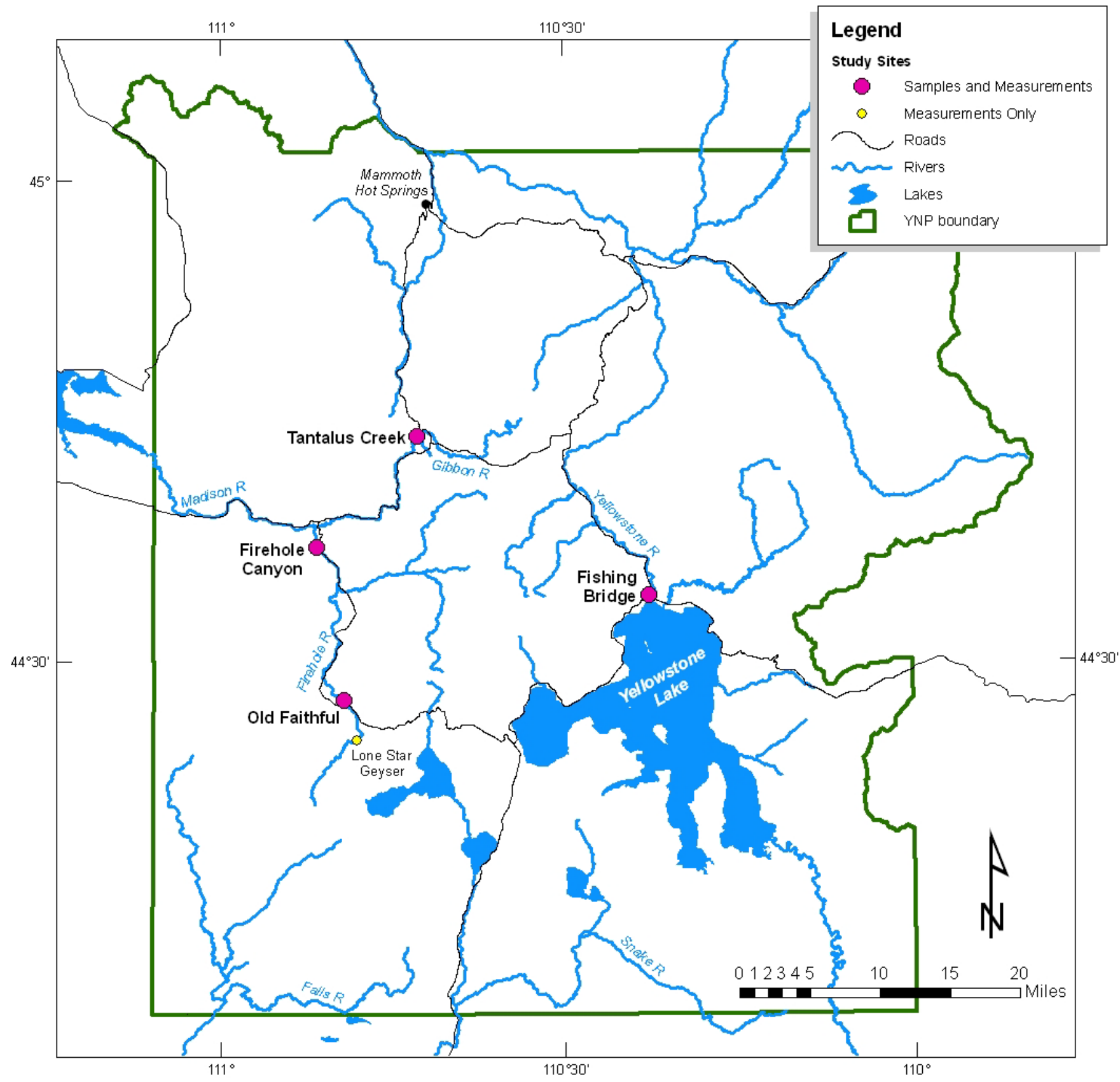

Figure 1. Map of sampling sites in Yellowstone National Park. 


\section{Appendix: Photo documentation of Instruments and Field Sites}

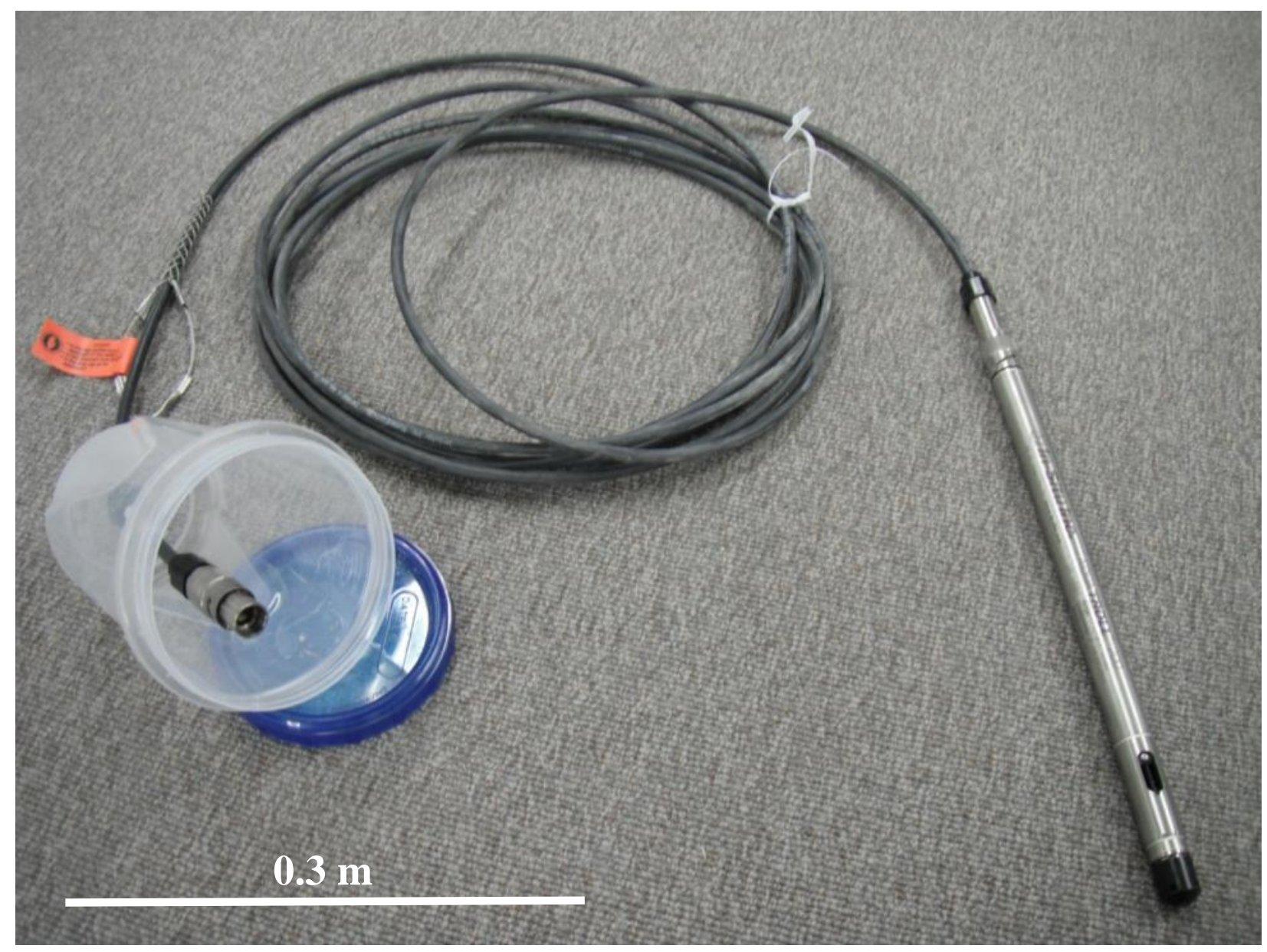

Photo 1. Aqua TROLL and cabling. Electronic connections at subaerial cable end were protected in a plastic container that was positioned on the stream bank. 


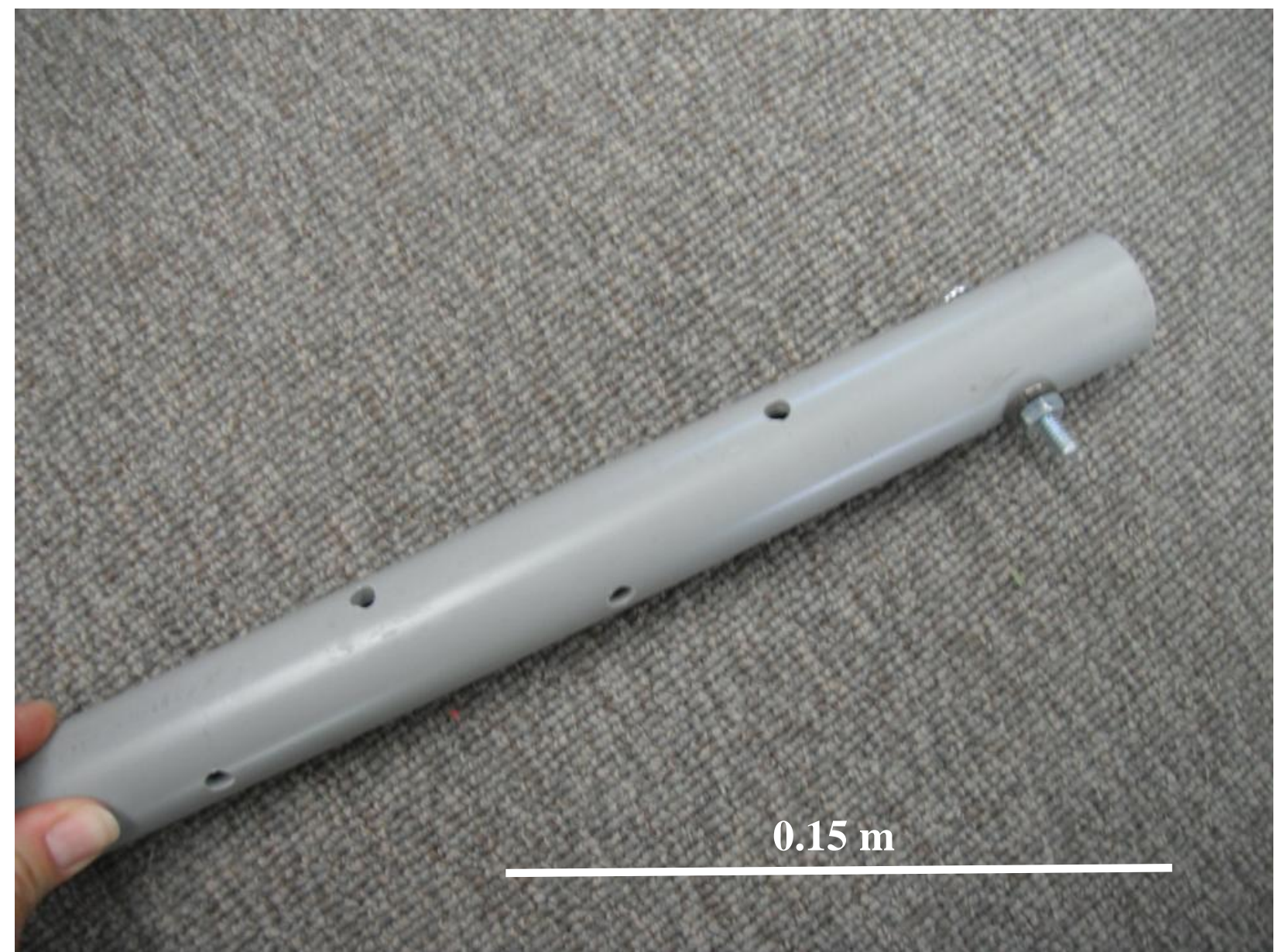

Photo 2. Bottom of 1.5-in diameter PVC pipe section, showing $6.35 \mathrm{~mm}$ holes that allow water to flow past the instrument. 


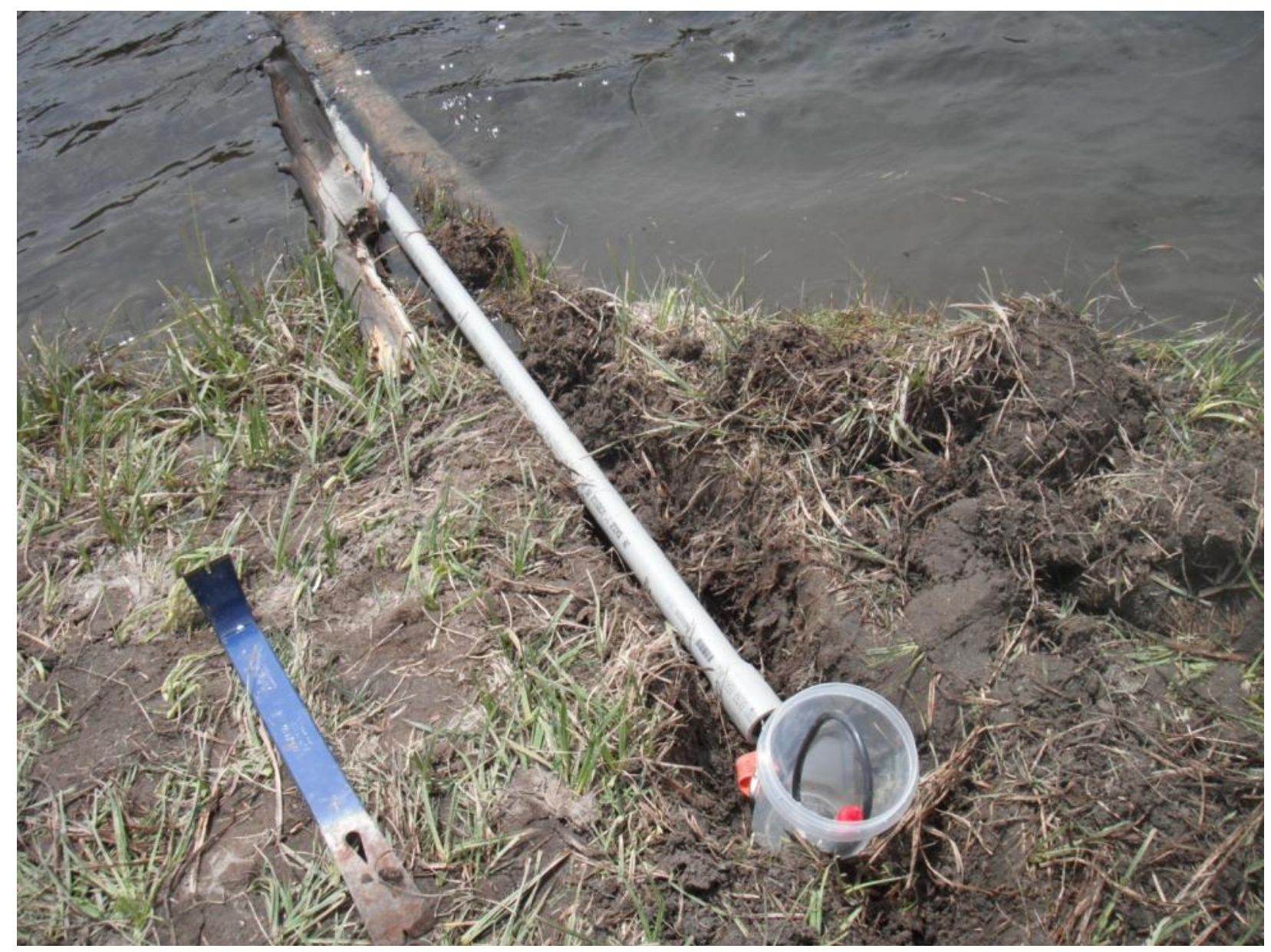

Photo 3. Installation of Aqua TROLL at Firehole Canyon site. PVC pipe encloses the TROLL and extends $\sim 8 \mathrm{ft}$ into the stream channel. TROLL cable emerges from the pipe onto the bank and is protected inside a plastic container. The pipe and container were subsequently buried. 


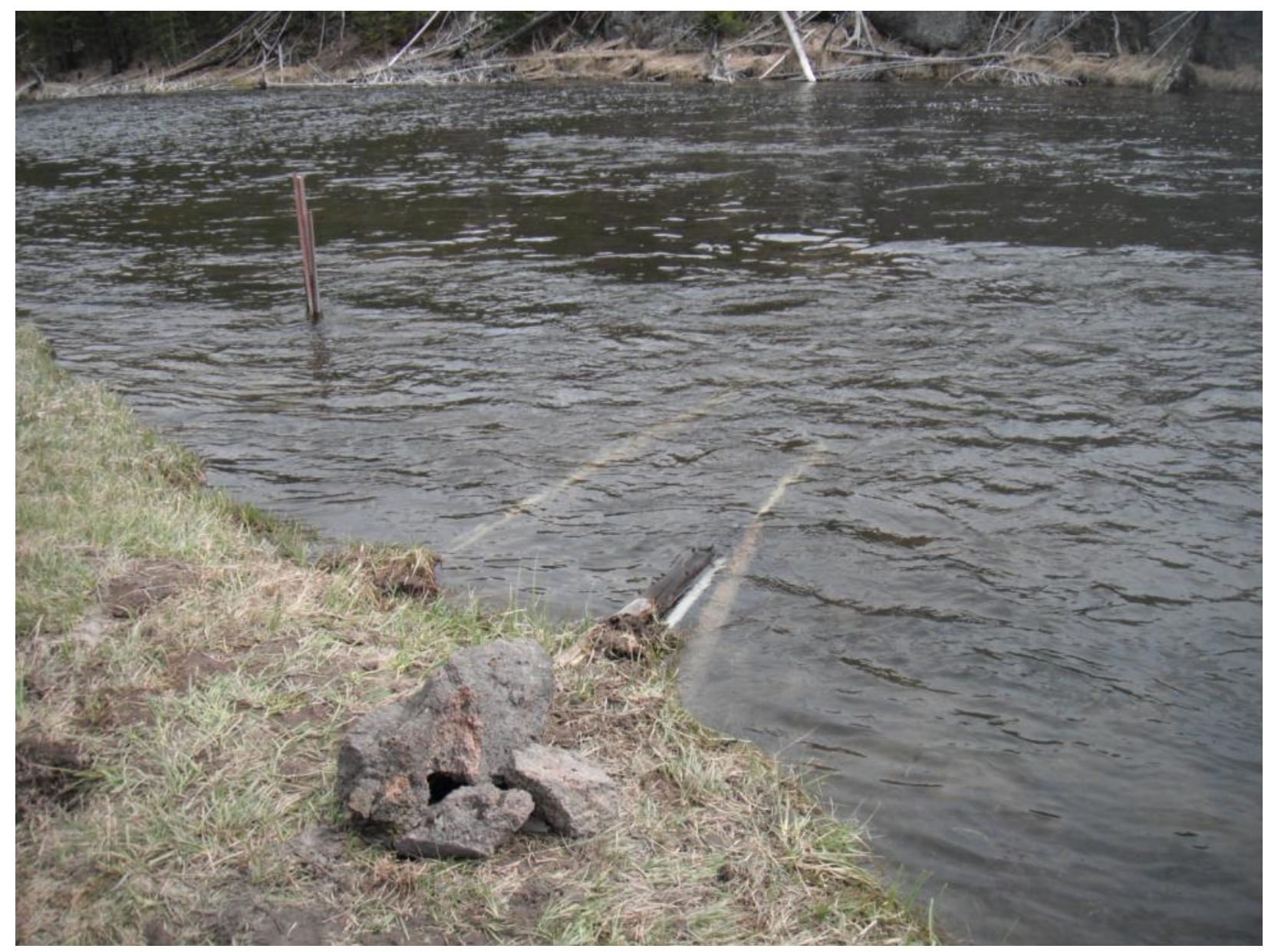

Photo 4. Completed Aqua TROLL site at Firehole Canyon. Pile of rocks covers the plastic container that protects the cable. PVC pipe containing the Aqua TROLL extends from the rock pile into the stream channel. A second pipe to the left contains conductivity instruments associated with the USGS gaging station. The staff plate for the gaging site is in the upper left of the photo. 


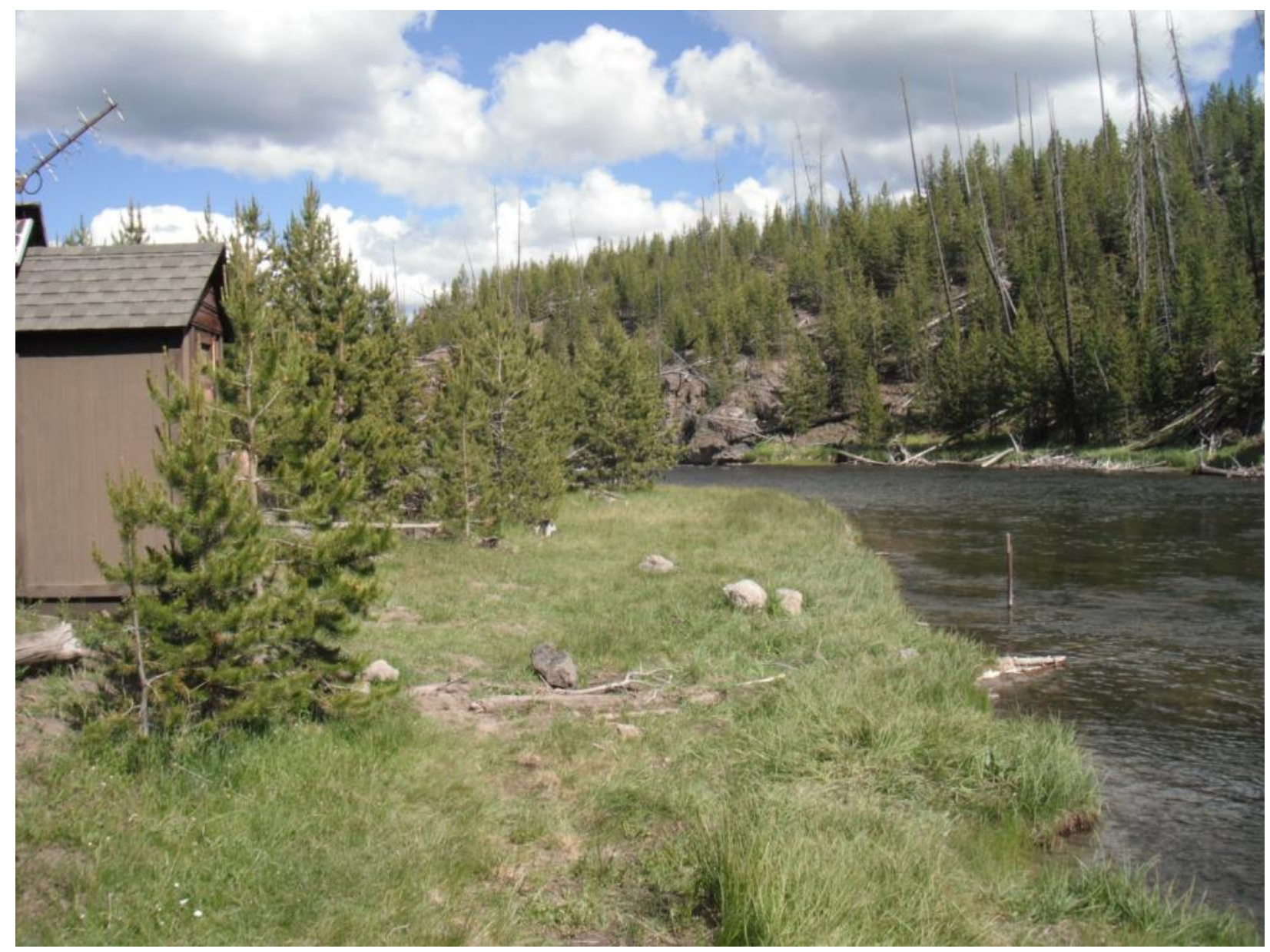

Photo 5. Overview of the Firehole Canyon site. 


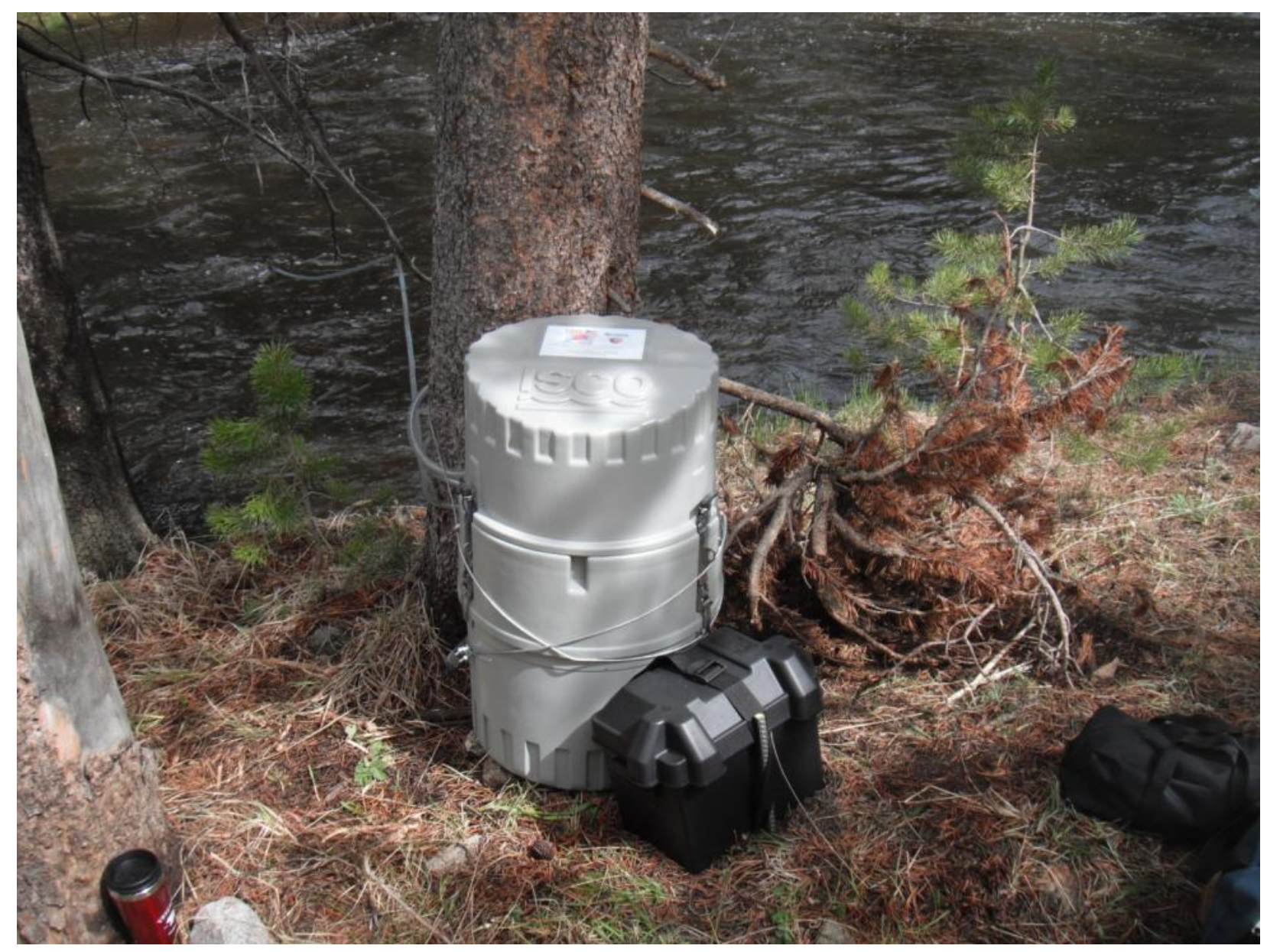

Photo 6. ISCO autosampler stationed on the stream bank at the Old Faithful site. The 12-V automobile battery that powers the unit is housed in the smaller black case. 


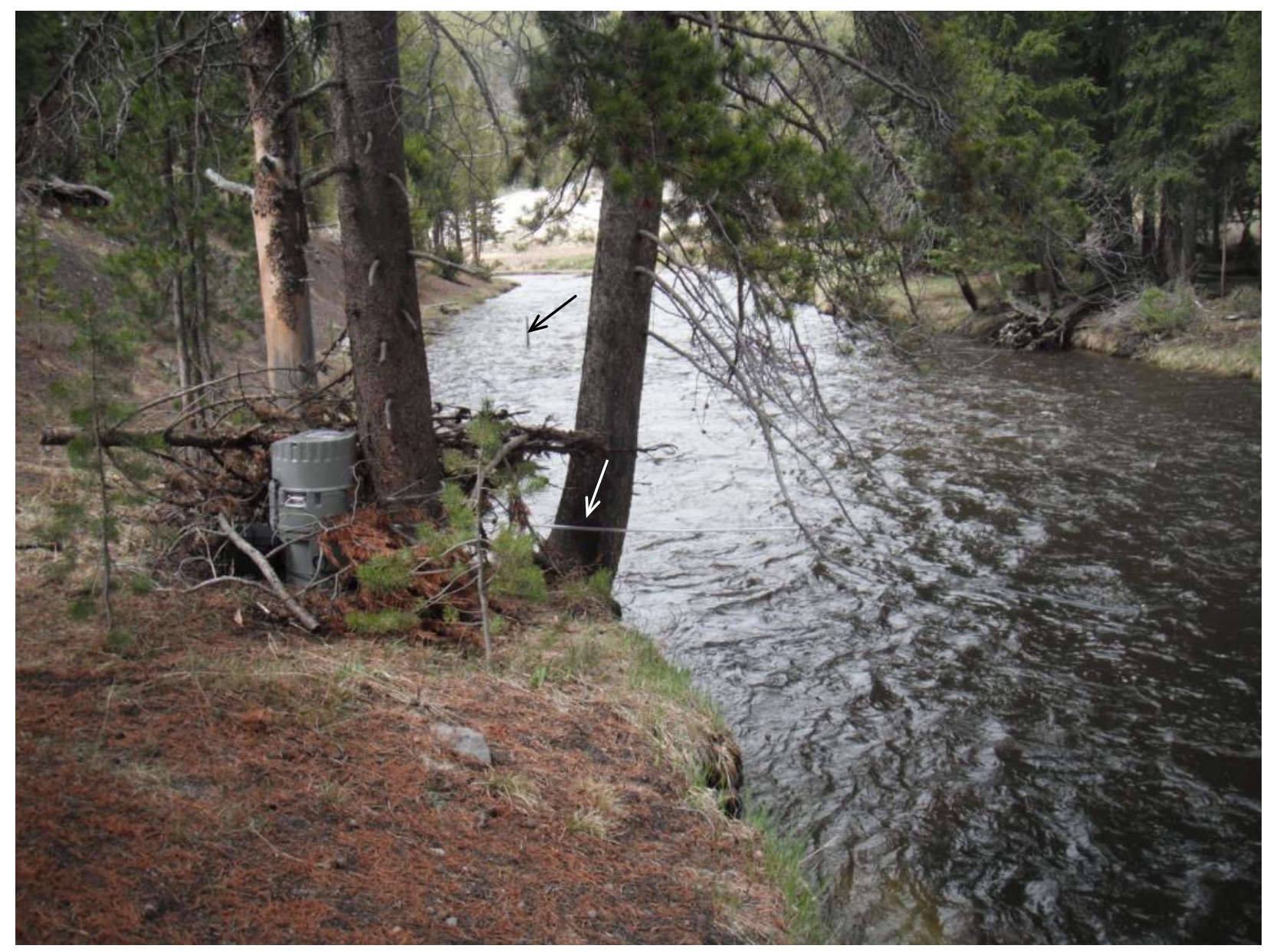

Photo 7. ISCO auto-sampler at the Old Faithful site is partially obscured by branches. The inlet tubing that extends out to the water is shown by a white arrow. The gaging station staff plate is visible in the background (black arrow). The Aqua TROLL is located $\sim 15 \mathrm{ft}$ downstream of the staff plate. 




Photo 8. Overview of the Fishing Bridge site. The PVC tubing containing the Aqua TROLL runs underwater along the downed tree in the foreground (black arrow). The subaerial end of the cable is inside a plastic container and hidden underneath the root mass of the downed tree (white arrow). The USGS gaging station is visible in the middle ground, and Fishing Bridge is in the background. 


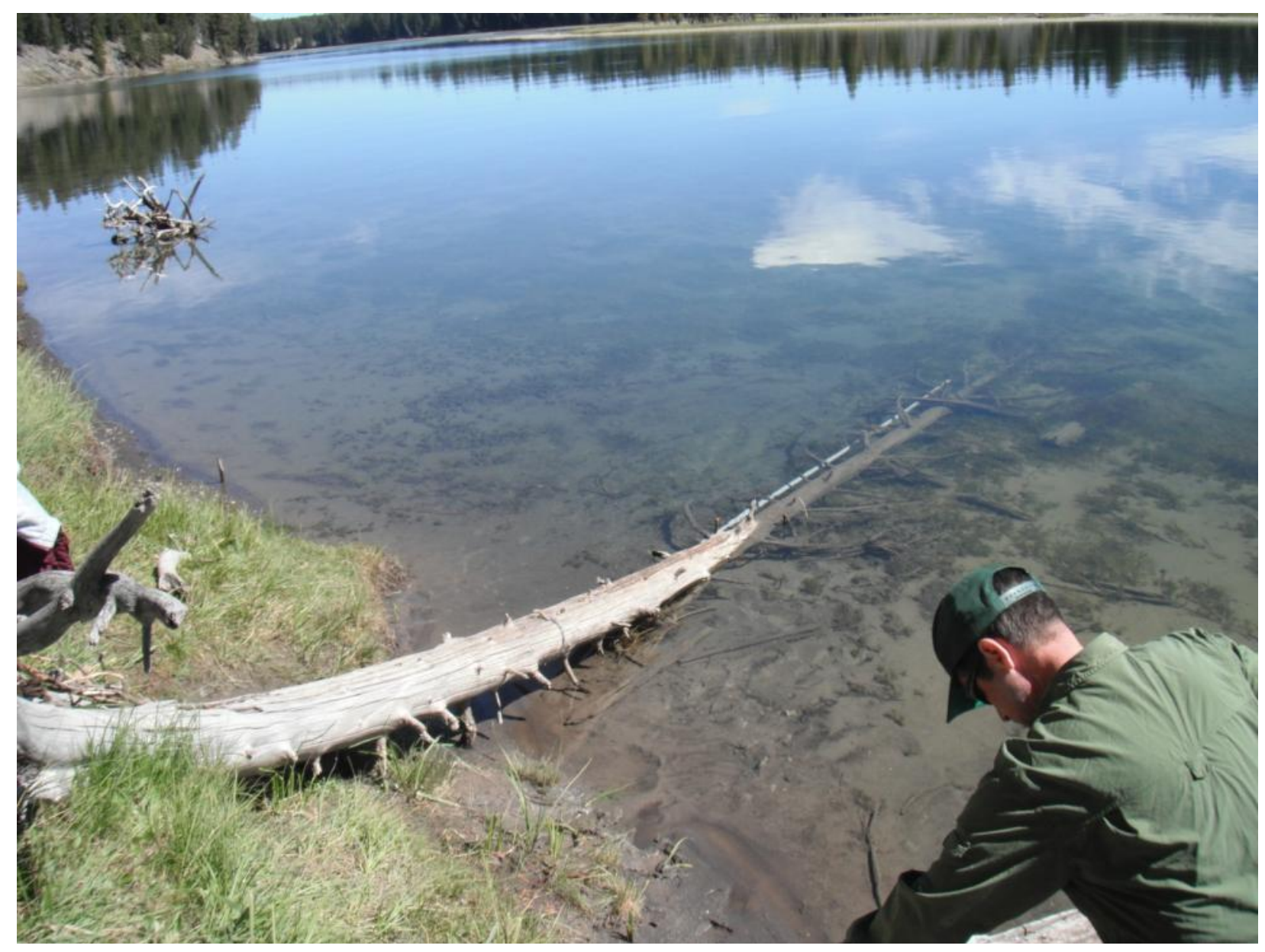

Photo 9. At the Fishing Bridge site, the PVC tubing housing the Aqua TROLL extends $20 \mathrm{ft}$ into the stream channel along a downed tree. 


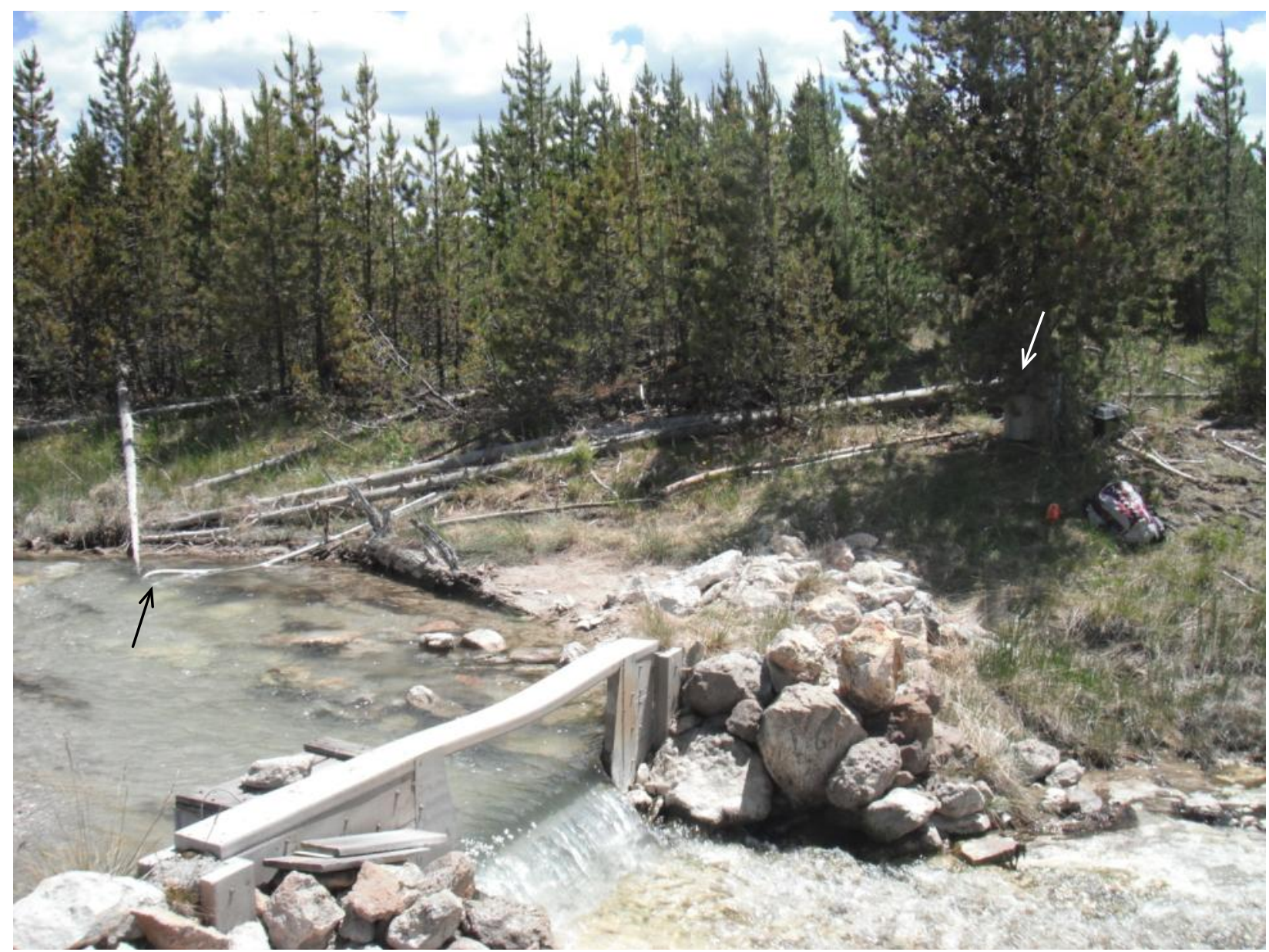

Photo 10. Overview of the Tantalus Creek site, including the Tantalus weir. The ISCO autosampler is located underneath the tree at right side of photo (white arrow), with inlet tubing extending down the stream bank to a pool at the left (black arrow). The Aqua TROLL is situated at the same location. 


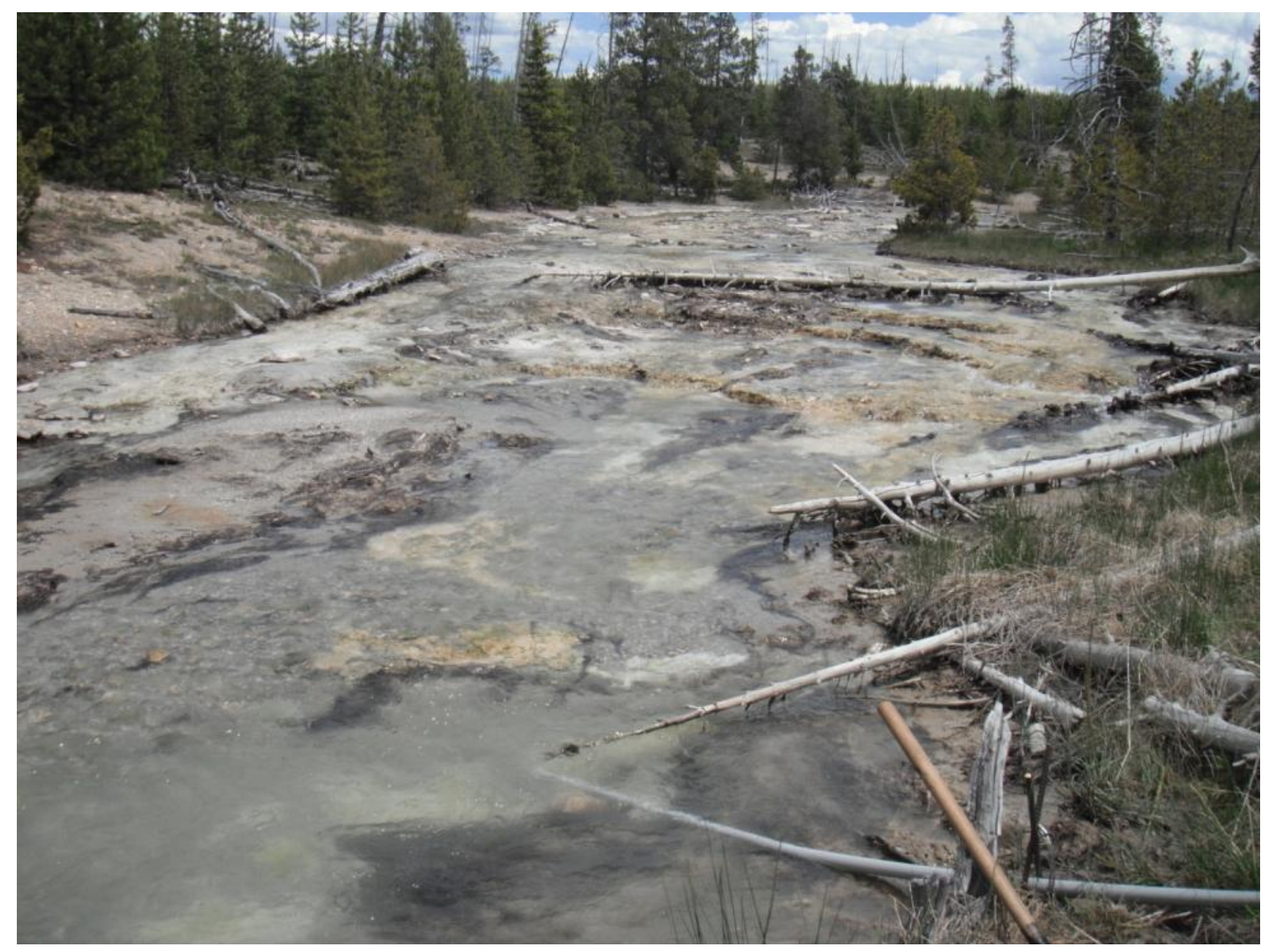

Photo 11. Looking upstream from the Tantalus Creek monitoring site. Grey PVC tubing housing the Aqua TROLL is visible entering a pool at bottom of photo. 